\title{
Naming in the language of the street
}

\author{
Vivian Cook \\ Newcastle University, UK \\ Vivian.Cook@ncl.ac.uk
}

\begin{abstract}
This paper looks at how street signs identify English streets and buildings. Street name signs mark out streets in forms regulated by government in terms of typeface and other attributes but not language. A building name or number sign provides a location and delimitation of property for legal and administrative purposes. Their meaning is highly indexical in that it is only true for a precise given location. Naming signs need to last indefinitely and to be legible from different angles and in different lights. Many use all capital letters, with serif letters conveying traditional values and sans serif modernity. The choice of material, whether stone, wood or paper, is crucial, to the extent that some naming signs are built-in to the actual architecture of the buildings. Naming signs have a range of functions and meanings based on physical qualities and physical location not found in printed texts.
\end{abstract}

Keywords: Street signs, writing, indexicality, naming, letters

\section{Resumen}

En este artículo investigamos el modo en que se identifican las calles y los edificios en Inglaterra. Los letreros con nombres de calles identifican las calles siguiendo las regulaciones del gobierno en términos de tipo de letra y otros atributos, pero no respecto al lenguaje. El nombre de un edificio o un número indican la situación y los límites de una propiedad a efectos legales e administrativos. Su significado es altamente indexical porque sirve únicamente para una sola situación determinada. Los letreros tienen que durar indefinidamente y ser legibles desde diferentes ángulos y con iluminación diferente. En muchos se usan letras mayúsculas, con letras tipo 
serif para marcar valores tradicionales y letras sans serif para indicar modernidad. La selección de materiales, sea piedra, madera o papel, es crucial, hasta el punto de que algunos letreros forman parte arquitectónica del edificio. Los letreros tienen una gama de funciones basadas en propiedades físicas y situación en el espacio que no se encuentran en los textos impresos.

Palabras clave: Letreros, escritura, indexalidad, nombrar, letras

\section{Introduction}

The city street is a place where people live and meet, flock to as workers, customers, and patients, and move through as pedestrians, bicyclists and drivers. The written language of the street reflects and enables this rich and many-sided life. This paper takes ideas from linguistics, from writing system research (Cook \& Ryan, 2016), from typography, broadly defined as "the craft of endowing human language with a durable visible form" (Bringhurst, 1992: 10), from linguistic landscape research (Landry \& Bourhis, 1997), which has concentrated on the choice between languages in street signs, and from research into the city (Hall, 2012; Zukin, Kasintz and Chen, 2016), which has looked at immigration and gentrification. The language of the street represents a novel area of applied linguistics research in its reliance on the theoretical and descriptive techniques of linguistics, in its multidisciplinary sources that have seldom previously been connected, and in its emphasis on language as actual concrete texts embedded in a material context. The present paper analyses how streets and buildings are identified through the written signs that name them.

This research forms part of a developing programme about the street sign (Cook, 2013a; 2013b; 2015), using a basic corpus of signs from Newcastle upon Tyne and Colchester in England. The focus of this paper is on permanent "official" naming signs - permanent signs as defined by Blommaert (2013) - rather than the more ephemeral name signs of restaurants, shops etc, and on name signs that indexically belong to particular places, not to names used in other ways, say on direction signs, to be dealt with elsewhere. 


\section{The naming of things}

\subsection{Street names}

Figure 1: Street name signs: Newcastle upon Tyne

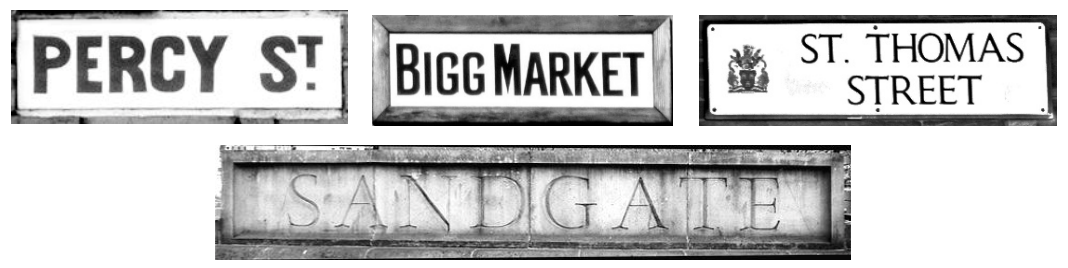

Street name signs identify streets, typically with at least one sign at each end. Identifying not only names something but also separates it from other things; an environmental image "requires first the identification of an object, which implies its distinction from other things, its recognition as a separable entity" (Lynch, 1960: 8). Figure 1 displays a range of typical street name signs from Newcastle upon Tyne.

The choice of street names is governed in the UK by local and national regulations. The texts have limited syntactic structure, consisting essentially of noun phrases without articles. The traditional use of road is to name roads after the places they lead to - most towns and suburbs around London have a London Road - while street names a builtup urban road that does not necessarily lead to the place it mentions, such as Oxford Street in London's West End. The City of London (2014) forbid the use of "Names of persons (living or dead)", "Names that endorse commercial marketing", and "Names ... capable of being misconstrued into inappropriate meanings". The restrictions are more flexible for alleyways, reflecting the wide variation in local dialects: Newcastle has Chare, Garth, Wynd and Haugh; Colchester adds Folley; many parts of England use Lane for alleyways, as in the Isle of Wight. The historic term gate, often meaning "way" rather than "opening in a wall", survives in a compound form in some street names, Scheregate and Headgate in Colchester, Gallowgate and Newgate in Newcastle.

Though the English language is used for virtually all street names in England, bilingual street name signs in Welsh and Gaelic are common in Wales and Scotland. In England, bilingual signs cluster in the areas where minority languages are spoken, say Bengali in Bethnal Green in London. Figure 2 shows a bilingual English/Chinese sign Stowell Street in Newcastle - a common feature of Chinatowns worldwide (Cook, 2017); incidentally the Chinese characters in the sign Stowell Street (Fig. 2) mean "Chinatown" rather than translating the street name. Unusually a new road built in the 2010s in Colchester, which prides itself on its Roman origins, has been given the Latin name 
Via Urbis Romanae (Fig. 2) ('Road of the Roman town'), with no English translation. No regulation explicitly requires street signs in England to be in English, with the exception of no-smoking signs (The Smoke-free (Premises and Enforcement) Regulations, 2006).

Figure 2: Non-English street signs: Newcastle (Stowell Street: English/Chinese); Colchester (Via Urbis Romanae: Latin)

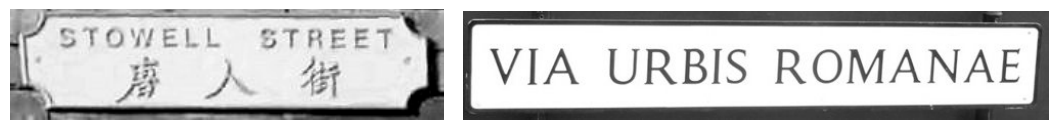

Though the nature of proper names is often disputed (Coates, 2009), names that identify particular locations are clearly numbered among them. The sign Percy St. (Fig. 1) might refer to the Percy Street in London, Philadelphia or Melbourne instead of the Percy Street in Newcastle upon Tyne illustrated. Proper names do not have unique reference, but have specific reference in a given context: John Brown may refer to a particular individual in one context and another person in another. A street name like Percy Street is then a type of proper noun referring to a particular place in context.

The Public Health Act 1925, Section 19 (1925) requires local authorities to make certain "the name of every street shall be shown in a conspicuous position", though anybody's experience will show this is often breached. Street name signs in England are usually attached to buildings as in Stowell Street (Fig. 2) or are on short poles at the side of the street as in Via Urbis Romanae (Fig. 2), but do not hang centrally over the street or project from lamp-posts at street corners, as they do in, say, New York.

\subsection{Building names and numbers}

The names of buildings are restricted in similar ways. Figure 3 shows some signs for Newcastle buildings: Bamburgh House is an "applied" letter sign for an office block using a print Garamond typeface; Cordwainers Hall, a nineteenth century sign cut into stone, doubtless re-cut in the 1990s when the area was restored - a cordwainer was a kind of leatherworker; Percy House, a sign painted on glass for an office block; Leazes Arcade, mid-twentieth century gilt letters. 
Figure 3: Building Names: Newcastle upon Tyne
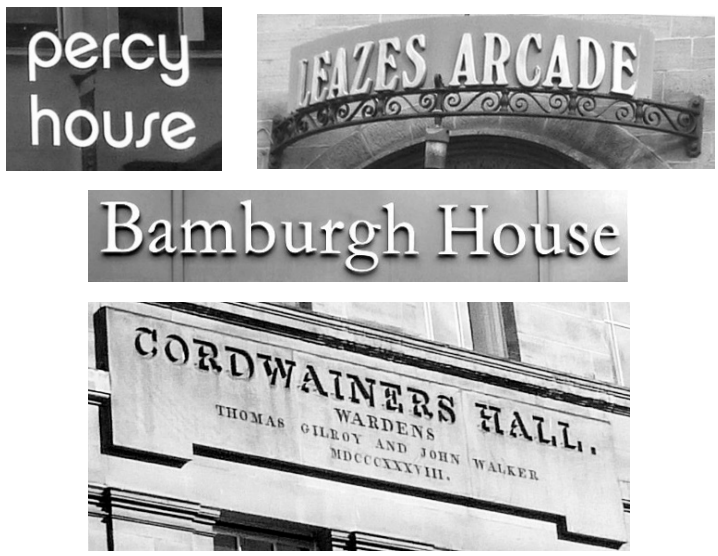

According to the City of London (2014) regulations, building names should not be difficult to pronounce or spell, and should not have more than three syllables. They "should not be named after living persons, with the exception of the Royal Family". Displaying a building name is no guarantee that this is still its current name: Leazes Arcade (Fig. 3) in Newcastle has long been student accommodation (and was built as a synagogue); Cordwainers Hall (Fig. 3) is now a nineteenth-century façade inside which lurks a 1990s shopping mall.

The primary label for a building for official purposes such as receiving mail or getting emergency services is in fact the number: names are optional extras. The variety of house number signs in Leazes Park Road in Newcastle is seen in Figure 4.

Figure 4: House Numbers: Leazes Park Road, Newcastle upon Tyne

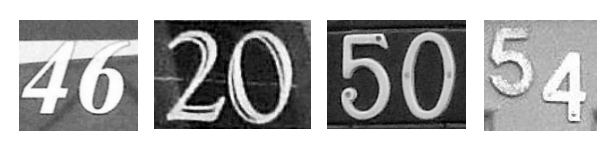

The meaning of numbers is again indexical: the sign 50 (Fig. 4) belongs to one building in one street, and to that building alone; moving it to another location destroys its reference. In England, odd numbers are typically allocated to one side of the road, even numbers to the other, allowable exceptions being the continuous numbering in cul-de-sacs. The Department of Transport circular (1993) decrees "Main roads should be numbered so that when travelling away from the centre of town the odd numbers are on the left hand side and even numbers on the right." Some streets do have consecutive numbering on the same side; most famously the Prime Minister in 10 Downing Street lives next door to the Chancellor of the Exchequer in 11 Downing Street - 
incidentally the $<10>$ displayed on the Prime Minister's door is actually a letter $\langle\mathrm{O}\rangle$, a mistake that has now become a tradition. The system of UK numbering differs both from the Japanese custom of numbering according to the order in which houses were built and from the common US system in which blocks start with a hundred. The City of London (2014) forbid the spelling out of numbers as letters: "authorised addresses must be numeric and not textual ... an address should be 1 Smith Street as opposed to One Smith Street"; their own web pages (City of London, 2015) nevertheless list the controversial building No 1 Poultry as One Poultry in breach of their own guidelines.

Thus the naming and numbering of places in the street is tightly controlled, on the one hand by authority, on the other by practical physical considerations, unlike other forms of written language. Based in part on Spolsky's (2009: 31) division of participants into "initiator or owner of the sign, the sign-maker and the reader", plus "a language management authority", Cook (2013a) distinguished five potential roles associated with street signs: the licensor of the sign, who regulates it; the owner of the sign, who owns it; the author, who creates the words of text displayed; the writer, who gives the text physical form; and the reader, who may be addressed particularly or be general. The local authority acting for the central government or on its own behalf is the licensor for all aspects of the street sign, the relevant aspect here being the regulation of names and numbers. However, such rules are primarly for new names and numbers; many existing ones breach them in one way or another, say London street names such as Austin Friars, Bevis Marks, Cloth Fair, Old Bailey and indeed Goswell Road, brought within the city by a boundary change.

The primary functions of naming signs include identification and location:

i) the identification of a particular place: you need to name something to be able to refer to it. The sign Percy Street (Fig. 1) identifies the street at both ends; Cordwainers Hall (Fig. 3) forms part of the actual building it identifies - "architectural lettering" (Baines \& Dixon, 2003). GeoPlace (the official body for addresses in the UK) (2016) proclaims "Everything happens somewhere". The precise identification of places is the basis for maps, title deeds etc. In England this comes down to entries in the Land Registry (https://www.gov.uk/government/ organisations/land-registry), which records the details of all property that has been sold in England since it started to operate.

The display of numbers is effectively compulsory: "Every number, name, or number and name, of any building in any street, shall be marked" (City of London, 2014). If the concept of property starts from land ownership - "Property ownership is the core of the capitalist system" (Price, 2011) - then the identification and naming of one's property is indispensable to Western capitalism. Foster and Iaone (2016) point out that "any articulation of the urban commons needs to be grounded in theory 
of property, or at least a theory about the character of particular urban resources in relationship to other social goods, to other urban inhabitants, and to the state".

ii) location: you need to know where something is to be able to get to it. The passerby needs to know they have reached their destination - "wayfinding". The Royal Mail and other delivery services need a specified postal address, now in part superseded by postal codes, which are not normally displayed on buildings though they feature in a few street name signs. Local authorities stress the need for emergency services to be able to identify locations, enabling "fast responses to emergencies by ambulance, police, and fire services" (City of London, 2014).

\section{Requirements for naming signs}

The requirements on the actual name sign are that it has to be durable, visible in all conditions and from all angles, and that it is decorative and expressive (Kinneir, 1980).

Figure 5: Building names and materials: Newcastle upon Tyne

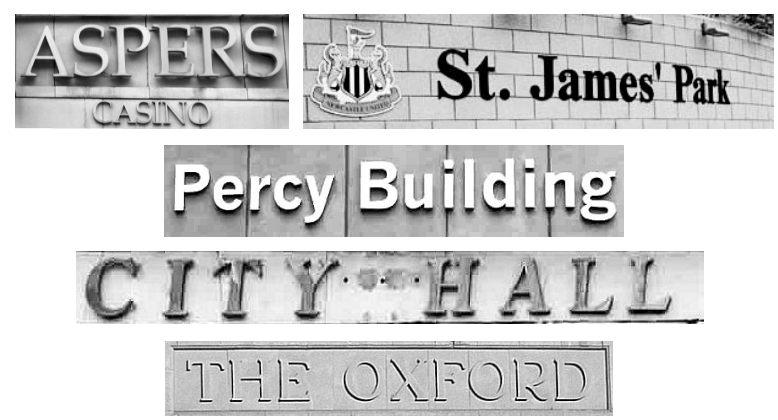

a) durability: name signs need to last

The material of these signs needs to be as indestructible as possible, unlike street ephemera such as fliers.

- stone is one historic choice for street name signs such as Sandgate (Fig. 1) and for important building names such as The Oxford (Fig. 5), which have letters cut into stone or raised from stone. Bartram (1978) points out that stone signs are essentially one-off designs by stone cutters and so permit subtle variation between signs, most notably in the street name signs of Bath, unlike standardised metal signs. All that looks like stone may not actually be stone, as in Dex Garage (Fig. 9), which is presumably moulded concrete. 
Figure 6: Street name signs and materials: Colchester (Constantine Road), Newcastle upon Tyne (rest)

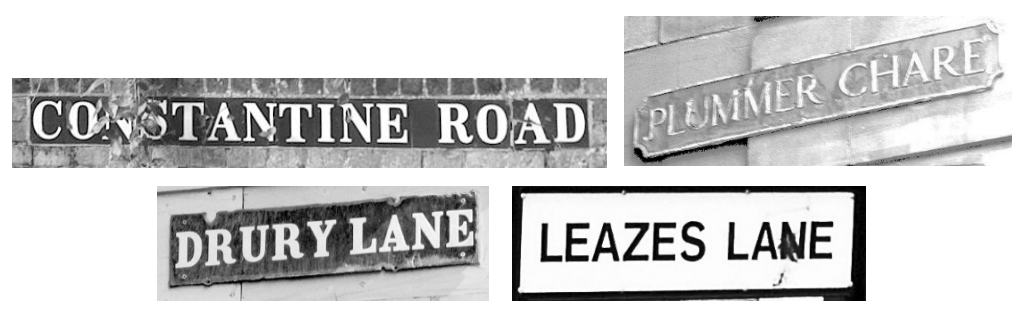

- metal is used in most street name signs, as in Leazes Lane (Fig. 6) and the signs in Figure 2, typically pressed letters in aluminium, though early signs were made of cast iron. To assert respectability, these need to be finished in silver, Percy Building (Fig. 5), or gilt, City Hall (Fig. 5) and Leazes Arcade (Fig. 2), particularly the brass of house numbers like, 54 (Fig. 4).

- ceramic tiles with individual white on black letters placed on brick walls were a Victorian style, still found in a handful of English areas such as Oxford, Hampstead and Colchester, as in Constantine Road (Fig. 6).

- painted black-on-white signs are exemplified in Percy St (Fig. 1). While raised metal or wooden letters are often painted, it is rare for a street name sign to be simply painted on a surface as here, presumably because of durability.

- building names and numbers are often painted or stuck on the inside of glass windows, as in Percy House (Fig. 3), 46 and 20 (Fig. 4); numbers are usually in gilt or etched on the glass.

- raised letters made of different materials may also be attached (technically "applied") to buildings, as in Bamburgh House (Fig. 3), Percy Building and Aspers Casino (Fig. 5), as may numbers in 12, 50 and 54 (Fig. 4), typically in brass or wood painted with gilt.

Apart from the physical requirements, the durability of these materials suggests the buildings and streets are permanent and well-established, and hence respectable. Cordwainers Hall (Fig. 3) suggests the endurance of this mid-nineteenth century building, misleading as this façade may be, as does the modern sign Sandgate (Fig. 1). Some buildings lay claim to such virtues by using signs that look old and durable "asserted permanence" (Cook, 2015). Hence the metal letters of Aspers Casino (Fig. 5) assert solidity and durability, not qualities commonly associated with casinos. Banks used to make similar claims through carved stone letters but now prefer the designed logo as it is more visible on the High Street than its stone counterpart (Gray, 1960). 
b) legibility: you need to be able to read it

Visibility depends on there being light to see the signs by. Few of these naming signs are individually lit in the dark, but depend on what is available from street lights etc - street name signs are required to "be fixed so that they will be illuminated by light from street lamps" (Department of Transport, 1993).

During daylight hours, the visibility of the signs relies on whatever natural light is available. The three-dimensionality of lettering is crucial to the legibility of raised or cut letters, which rely on shadows being cast (Gray, 1960), as seen dramatically in Laing Art Gallery (Fig. 7) and more subtly in the signs in Figure 5. In general, sansserif letters cast better shadows because of their simpler lines, as in Percy Building (Fig. 5); complications occur when there is a gap between the letters and the wall, as seen in Conservative Club (Fig. 7). Indeed painted signs often have a painted-in shadow to increase the visibility of the letters, as in 20 (Fig. 4). Signs in London may need to be cut deeper than signs in Rome to compensate for the weaker sunlight (Kinneir, 1980).

Figure 7: Letters and shadows on building names: Newcastle upon Tyne (Laing Art Gallery), Colchester (Conservative Club),

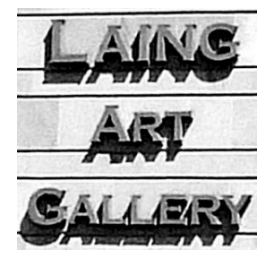

Legibility is also related to location: does a sign need to be read from a few feet away or from many yards? The 45 foot high Hollywood sign for instance is visible over much of Los Angeles. While name signs in England are usually on a vertical wall, some may be underfoot, such as mosaic entrance tiles. Unlike the standard reading distance and angle for printed books etc, reading distance and angle of presentation vary.

Figure 8: Coloured-in stone letters in building names: Colchester (Hospital); Newcastle upon Tyne (Northumberland House)

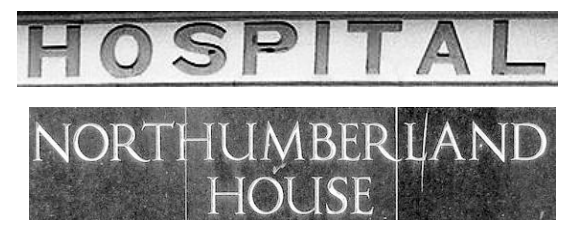


Figure 8 demonstrates the use of colouring in letters, typically gold (Northumberland House) or red (Hospital). Historically this goes back to the earliest Roman inscriptions such as Trajan's Column (AD 113) being painted in red lead (Gray 1960). To some extent the use of shadows in three-dimensional letters is thus a modern development.

Kinneir (1980) points out that legibility is not all. Well-known signs may be instantly recognised even if they are far from legible: the McDonald Golden Arches or the Starbucks siren don't need words. The sign Conservative Club (Fig. 7) is hard to read because the letters are attached to horizontal bars and the shadows of the letters fall awkwardly, but this hardly prevents the members of the party from finding it.

\section{Meaning and naming signs}

The naming signs of the street have their own peculiar types of meaning. Putting the signs up in effect creates their meaning, subject to licensing by the local authority: a building becomes Percy House when it is labelled Percy House. The meaning is indexical in that the signs refer to the street or building they belong to, a characteristic of proper names called "nomination" - "the bestowal of an expression on an individual to serve as a distinguishing mark" (Coates, 2009: 434). Name signs are not, however, indexical in the sense that they indicate a particular direction like a fingerpost.

This aspect of meaning is not peculiar to street names: christening a child Violet creates a name for a person; naming the areas inside lines drawn arbitrarily on the map creates "new" countries, such as Syria and Palestine after the fall of the Ottoman Empire. The naming signs of the street are uniquely bound to the architectural spaces in which people have laid out the places where they live. Naming turns space into place (Tuan, 1991).

Their meaning is also exophoric: "the identity presumed by the reference item is recoverable from the environment of the text" (Halliday \& Mattheisen, 2014: 624). The sign Percy Street (Fig. 1) exophorically labels the street it is attached to, just as Percy House (Fig. 3) labels a building. As Backhaus (2007: 6) puts it, "a public sign makes sense only in combination with its referent". This characteristic of street naming signs is similar to labels on packets, titles on books and the like. If the Percy Street sign were taken down and put up in Stowell Street, the words would be the same but they either be a lie in claiming the street had changed its name, or they would be purely decorative, like Carnaby Street signs sold to tourists in London. The meaningful use of naming signs is inseparable from the objects they are attached to. 
Scollon and Scollon (2003) have indeed emphasised the indexical and exophoric use of street signs under the heading of emplacement - "the act of placing a sign in its physical location to activate its meaning" (p. 210). The naming signs, however, have additional elements. One is the actual naming of the building or street as a sign of ownership or demarcation, differing from directional signs with arrows etc, which may be indexical in terms of orientation but do not assert identity. While the names of restaurants and businesses also confer identity, street and building signs claim an enduring identity that requires their recording in the Land Registry etc; in other words, there is a distinction between the name of the building in its primary address function, say Percy House, and the business that occupies it, even if sometimes these are one and the same, as in Aspers Casino (Fig. 5).

\section{Capital letters and lower case}

\subsection{The use of capitals in street name signs}

Capital letters have always dominated identification signs. To some the demands of a "bicameral" alphabet meant that capitals and lower-case combine awkwardly because they come from different historical sources; Tschichold (1928/1998: 81) indeed suggested abandoning capital letters altogether. Street name signs in England are almost invariably written in all-capitals, as in Figures 1,2 and 5, unlike the lowercase letters used in say Norway, Germany and France. The only exceptions may be the small capital $\langle\mathrm{T}\rangle$ in abbreviations for Saint or Street as in Percy St. and St. Thomas Street (Fig. 1) and the small capital $\left\langle_{D}>\right.$ in abbreviations for Road. Small-capitals also combine in occasional signs with word-initial capitals as in Bigg Market (Fig. 1).

The rationale for all-capitals is "to avoid confusion with traffic signs, which generally employ lower-case lettering" (Department of Transport, 1993). Traffic signs also combine word-initial capitals with lower case letters to conform with the influential research by Kinneir and Calvert (Kinneir, 1980) into motorway signs, commissioned by the then Ministry of Transport. While the demands for letters read from speeding cars obviously differ from those read by pedestrians and from slow-moving vehicles, the extra legibility of lower case is surely a factor in both contexts.

\subsection{Use of capitals and lower-case in building names}

Capitals and lower case letters are used slightly differently in building name signs. Many are indeed written entirely in capitals, such as both the building name signs in Figure 8, three of those in Figure 3 and two in Figure 5. Some signs use a smaller size 
of capital letter (not quite the same as conventional modern small-capitals), such as Laing Art Gallery. Word-initial capitals are found in Bamburgh House (Fig. 3) and Percy Building (Fig. 5), following the convention of initial capital letters for proper names. Nevertheless signs with all lower case letters are also found as in Percy House (Fig. 3).

Building signs then vary more than street name signs and so have more individuality. While street name signs are licensed by the local authority, the owner decides the form of the building name sign (with the exception of conservation), as does the role of the writer in creating unique signs. The owner may decide the overall style, the material to be used etc, to define respectability and identity. Stone in particular involves the craft of stone-cutting and so "quality" can be revealed through individual craftsmanship.

\section{Serif and sans serif letters}

A serif consists of "the broadening of triangular forms at the terminals of letters" (Hill, 2010: 186), seen clearly at the tips of the cross-stroke and feet of the $\langle\mathrm{T}\rangle$ in St Thomas Street (Fig. 1). This is a consequence of the way that Roman stone inscriptions were made by first drawing an outline of the letter with a square-tipped brush, faithfully reproduced by the chisel as a serif (Catich, 1968). A second consequence of the original brushwork is that the line varies in width within a letter, again followed by the chisel. Serifs and varying line width can be seen in the Roman-style letters of Sandgate (Fig. 1) and the letters of Bamburgh House (Fig. 3) or in the fat serif letters of Drury Lane versus the even width sans serif letters of Leazes Lane (Fig. 6). Further examples of serif capital letters can be seen in St. Thomas Street (Fig. 1) and Via Urbis Romanae (Fig. 2) and in Cordwainers Hall and Leazes Arcade (Fig. 3).

The sans serif letters are partly the reverse of this, i.e. no serifs and an even line width, as in Bigg Market (Fig. 1) and Stowell Street (Fig. 2). The two characteristics of serifs and even line-width are not necessarily found together; sans serif Monument Mall (Fig. 9) has varying line width and serif Laing Art Gallery (Fig. 7) has almost even line-width. Nevertheless the division into serif and sans serif letters is fundamental to the discussion of letters in the modern Roman alphabet. It also applies to the house numbers seen in Figure 4, of which 50 and 20 are clearly serif numbers with varying line width, 54 nonserif with constant width, 46 non-serif with varying width (and italic).

\subsection{Serifs and sans serifs in street names}

St. Thomas Street (Fig. 1) and Via Urbis Romanae (Fig. 2) show the typical serif capital letters of modern street-name signs in England, using the Kindersley typeface 
recommended by the Department of Transport (2015). Percy Street and Bigg Market (Fig. 1) (for the curious, named after Biggs barley rather than its size) show differing sans serif forms, while Leazes Lane (Fig. 6) is the official sans serif Gill Sans typeface (Department of Transport, 2015).

\subsection{Serifs and sans serifs in building names}

Most of the building names rendered in stone consist of serif capitals, as in Cordwainers Hall (Fig. 3) and The Oxford (Fig. 5), with occasional exceptions in sans serif like Hospital (Fig. 8). Incised letters can have more delicate serifs as in Sandgate (Fig. 1) than raised letters as in Leazes Crescent (Fig. 9), for technical reasons to do with working stone (Kindersley \& Cardozo, 1990). Those letters vary between serif as in Leazes Arcade and St James' Park (Fig. 3), and sans serif as in Percy Building (Fig. 5). The only examples on glass are the sans serif lower-case Percy House (Fig. 3) and the house number 20 (Fig. 4).

\section{Materials, letters and quality}

Let us now put these features of naming sign letters into a continuum of quality using three criteria from Scollon and Scollon (2003: 135).

- permanence. Naming signs aim to last as long as the buildings and streets they name. The only signs with even longer lives are inscriptions, Trajan's Column in Rome having lasted nineteen hundred odd years, the Behistun inscription in Iran some two thousand five hundred. Buildings and streets with the most claim to permanence may have their names writ in stone, as in Cordwainers Hall (Fig. 3) and Sandgate (Fig. 1), metal like St. Thomas Street (Fig. 1) and City Hall (Fig. 5), or tiles as in Constantine Road (Fig. 6). According to Cook (2015), signs like Aspers Casino (Fig. 5) assert permanence for commercial reasons rather than because of the actual longevity of their existence.

- temporality/newness. While in a sense all naming signs are permanent compared to notices made of paper, there is nevertheless some variation in building name signs in terms of the serif/sans serif divide. Most all-capitals building signs have serif letters, like The Oxford (Fig. 5), with the exception of Hospital (Fig. 8). Word-initial capitals like St. James's Park (Fig. 3) are also usually serif. The lower case building sign, Percy House (Fig. 3), however, is sans-serif, thus presumably asserting its newness and modernity. While the signs were all photographed in the 2010s, they fossilise different eras of history both in their form and in their names. Mid-nineteenth Cordwainers Hall (Fig. 9), 1902 Law Courts (Fig 9), 1931 Dex Garage (Fig. 9) and 1980s Leazes Arcade (Fig. 3) 
are reminders of particular ages and styles, even if they are now purely decorative in that they name buildings that no longer exist except as shells for other functions.

- material. Mostly quality comes down to the material that is used for the sign and the craftsmanship necessary for making it. Stone is expensive and its engraving highly skilled work: stone signs like Sandgate (Fig. 1) score highly for quality. Adding gilt is another sign of quality, seen in Northumberland House (Fig. 8). Gold colouring adds quality to attached letters like those in City Hall (Fig. 5) and Leazes Arcade (Fig. 3) and to house numbers, as in the number signs in Figure 4. The other valued colour for quality is silver, as in Percy Building (Fig. 5). Blue is sometimes used, as in Laing Art Gallery (Fig. 7), though the blue of Conservative Club (Fig. 7) is probably predetermined by the colour of the Conservative Party. The less typical sans serif signs like Hospital (Fig. 8) are the only ones in red. Thus a limited palette of colours is used on name signs, partly for reasons of visibility, partly for quality.

We must not, however, forget Kinneir's remark "We seldom react to letterforms alone but to legends in their entirety - letterstyle, content, colour, material, size and position" (Kinneir, 1980:14). The reaction is to the sign as a whole, one reason why so many complete signs have been displayed here rather than cited.

\section{Architectural signs}

In their seminal study of the Las Vegas Strip, Venturi, Brown, and Izenour (1977) concluded that the sign may be as significant architecturally as the actual building. Figure 9 provides some examples of naming signs used as integral parts of buildings. Leazes Crescent is moulded into the roof line of a mid-nineteenth century terrace; Dex Garage extends the height of a 1930s car park. The Edwardian sign Law Courts is built into the entrance portico and has two notable features: the archaic use of $\langle\mathrm{V}\rangle$ for $\langle\mathrm{U}\rangle$ and the neat ligature of $\langle A\rangle$ and $\langle W\rangle$ into a single form . Central Arcade uses applied gilt letters in a tall Edwardian script. Cordwainers Hall (Fig. 3) is a further nineteenth century example where the sign is built-in to the front of the building. 
Figure 9: Architectural name signs: Colchester (Law Courts), Newcastle (rest)
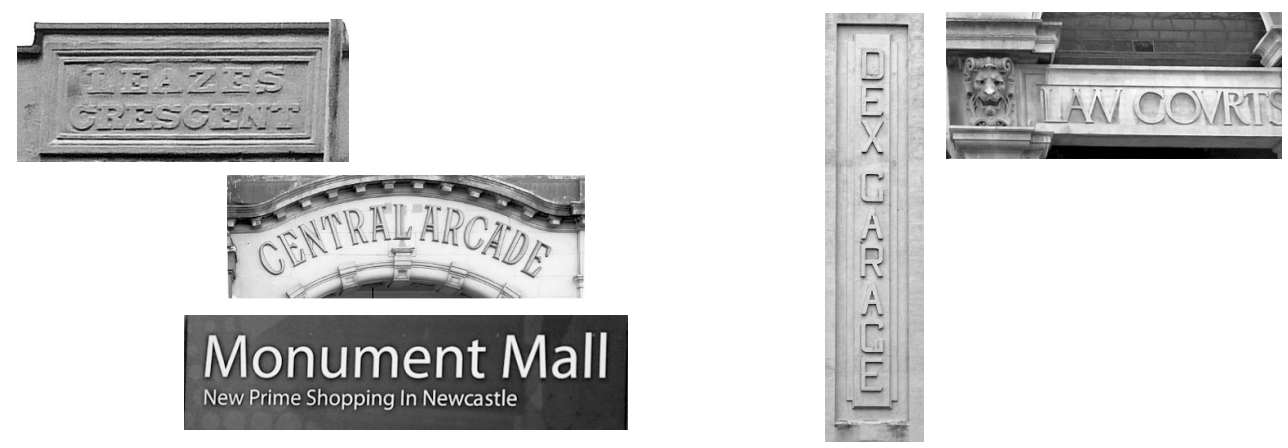

A unique aspect of some street signs is that they are "architectural", that is to say they form a significant part of the object they name (Baines \& Dixon, 2003), as in Cordwainers Hall (Fig. 3), typically in stone in an arch or portico as in Hospital (Fig. 8). These range from Leazes Crescent (Fig. 9), where the sign is an essential part of the building design, to the art deco sign Dex Garage (Fig. 9), where it dominates the whole elevation for three storeys, to Central Arcade (Fig. 9), where it complements the arch that houses it. Both Dex Garage and Leazes Crescent are indeed part of the actual fabric of the building. In each of these cases, the sign, in very large capital letters, is designed into the building so that building and sign are one.

Nevertheless most naming signs are not integrated with the structures themselves but enclosed in rectangular panels, either with borders marked out as in Sandgate (Fig. 1), or framed by a rectangular object like the window frame in Percy House (Fig. 3). Mostly these are landscape mode with one or two lines of text as in Constantine Road (Fig. 6), occasionally square like Laing Art Gallery (Fig. 7). A vertical naming vertical sign like Dex Garage (Fig. 9) is rare in England, though it not uncommon for shop and restaurant name signs.

\section{Conclusions}

Naming signs are a complex and interesting area of the language of the street, impinging on different aspects and functions of language.

1. They have a unique relationship to meaning. On the one hand, they are indexical in that their meaning relates to their precise location - the building or the ends of the street they are attached to: moving the sign destroys its meaning. On the other hand, they are performatively creating meanings by nominating the objects they are attached to: installing the sign gives the 
objects their names, like launching a ship. In this function, the naming sign is not there to be read but to proclaim, to stake a claim. Interaction with a reader or addressee is virtually beside the point.

This meaning of street or building names only exists if it is sanctioned by the relevant authority, ultimately through Acts of Parliament. Not only the choice of words in the signs but also the letter forms and display and their location have to meet the regulations. Naming signs are integrated with the law of the land in precise ways, requiring an official licensor as well as an owner. The two-way distinction between top-down and bottom-up signs (Ben-Rafael et al, 2006), often encountered in the linguistic landscape literature, does not do justice to the complexity of street signs, which are all licensed from above, but may be owned, authored and written by different people.

2. As well as these functions, name signs also have connotative and decorative characteristics. The connotations of identity and quality derive from the materials they are made of and the choice of letter forms, and so on. The decorative qualities may come from their integration into the whole building e.g. Dex Garage (Fig. 9) where the visual character of the building is partly created by the sign.

3. Hence the actual form and material of the letter is crucial. In speech, allophones of phonemes rarely represent meaningful choices; a speaker does not have the option of saying Bill /bil/ with the clear /l/ of lip, except when they are mimicking a particular accent. But the choice between different forms of the same letter contributes to the meaning: a $\langle\mathrm{P}\rangle$ means something different from a $\langle p\rangle$ or a $\langle p\rangle$.

4. A clear theme that emerges is that, unlike printed books or notices, naming signs have three dimensions; they can be raised from the surface as in The Oxford (Fig. 5), cut into it as in Cordwainers Hall (Fig. 3), or stand free of it as in Conservative Club (Fig. 7). Their three-dimensionality relates in particular to the kinds of shadow they show and to the solidity they convey and they have to work for different viewing angles. The most extreme three-dimensional form is when, say, the sign is a free-standing sculpture of numbers or letters by the entrance. In this respect, naming signs differ from most other street signs, which are essentially two-dimensional.

Much of this discussion has illustrated the peculiarities for name signs in letterforms, use of capitals etc. This might be taken as implying that these are somehow deviations from the "standard" English writing system; it is indeed easy to say, for 
example, that the use of capitals deviates from the standard usage for print. However, this is to accord a particular status to printed prose - the text in books, newspapers etc - rather than treating each variety of writing in its own right. The language of the street has a longer pedigree than the language of the printed book and in a sense established a prior standard that the printed page tries to live up to: the capitals of name signs, of inscriptions on war memorials and tombs, and of memorial plaques are something to emulate. The name signs establish conventions and standards of their own rather than being a spinoff from other standard forms. The study of written language in applied linguistics is the poorer for having neglected everything but the writing system of the printed book. The study of written language needs to be broadened from linearised printed texts, which under-represent many crucial aspects of writing manifested in street signs. While language teaching texts have often used street notices as stimuli for learning tasks, they have not systematically helped the students to see their nature and meanings. Clearly this will be an important area for the applied linguistics of the twenty-first century to explore; the mainstream study of applied linguistics has paid too little attention to the foundations of writing in physical, visible reality.

\section{References}

Backhaus, P. (2007) Linguistic Landscapes. Clevedon: Multilingual Matters.

Baines, P. and C. Dixon (2003) Signs: Lettering in the Environment. London: Lawrence King.

Bartram, A. (1978) Street: Street Name Lettering in the British Isles. London: Lund Humphries.

Ben-Rafael, E., Shohamy, E., Amara, M.H. \& Trumper-Hecht, N. (2006) Linguistic landscape as symbolic construction of the public space: the case of Israel. In Gorter, D. (ed) Linguistic Landscape: a New Approach to Multilingualism. Clevedon: Multilingual Matters, 7-30.

Blommaert, J. (2013) Ethnography, Superdiversity and Linguistic Landscapes. Bristol: Multilingual Matters.

Bringhurst, R. (1992) The Elements of Typographic Style. Vancouver: Hartley and Marks.

Catich, E.M. (1968) The Origin of the Serif: Brush Writing and Roman Letters. Davenport, Iowa: The Catfish Press.

City of London (2014) Street Naming and Numbering Advice Note. http://www. cityoflondon.gov.uk/services/environment-and-planning/planning/planning 
applications/submitting-planning-applications/Documents/city-of-london-snnadvice-note-oct-2014.pdf.

City of London (2015) Modern Architecture. http://www.cityoflondon.gov.uk/ things-to-do/visit-the-city/art-architecture/Pages/modern.aspx?page=all

Coates, R. (2009) A strictly Millian approach to the definition of the proper name. Mind $\mathcal{E}$ Language, 24: 433-444.

Cook, V.J. (2013a) The language of the street. Applied Linguistics Review, 4: 43-81.

.... (2013b) Standard punctuation and the punctuation of the street. In M. Pawlak and L. Aronin (eds.) Essential Topics in Applied Linguistics and Multilingualism, Switzerland: Springer International Publishing, 267-290. $181-109$

…. (2015) Meaning and material in the language of the street. Social Semiotics, 25,

-....(2017)Chinatowns.http://www.viviancook.uk/BilingualNotices/Chinatowns. html.

Cook, V.J and D. Ryan (eds.) (2016) The Routledge Handbook of the English Writing System. Abingdon: Routledge.

Department of Transport (1993) CIRCULAR ROADS 3/93 http://webarchive. nationalarchives.gov.uk/20100304070241/http://www.dft.gov.uk/pgr/roads/tpm/ tal/circulars/ular393streetnameplatesa4055.pdf.

Department of Transport (2015) Consultation on the Draft Traffic Signs Regulations and General Directions 2015 www.gov.uk/government/uploads/system/ uploads/ attachment_data/file/307150/draft-dft-circular.pdf.

Foster, S.R. and C. Iaone (2016) The city as a commons. Yale Law and Policy Review, Vol. 34, No. 2, 2016 , doi.org/10.2139/ssrn.2653084.

Geoplace (2016) Address Data. https://www.geoplace.co.uk/addresses\#sthash. PL2OrKK6.dpuf.

Gray, N. (1960) Lettering on Buildings. London: The Architectural Press.

Hall, S. (2012) City, Street and Citizen: The Measure of the Ordinary. Abingdon: Routledge

Halliday, M.A.K. and M.I.M. Matthiessen (2013) Halliday's Introduction to Functional Grammar. Fourth edition. Abingdon: Routledge.

Hill, W. (2010) The Complete Typographer. Third edition. London: Thames and Hudson. 
Kindersley, D. and Cardozo, L.L. (1990) Letters Slate Cut. Cambridge: CardozoKindersley Editions.

Kinneir, J. (1980) Words and Buildings. London: The Architectural Press.

Land Registry, The (2015). https://www.gov.uk/government/organisations/landregistry.

Landry, R. and R.Y. Bourhis (1997) Linguistic landscape and ethnolinguistic vitality: an empirical study. Journal of Language and Social Psychology 16, 23-49.

Lynch, K. (1960) The Image of the City. Cambridge, Mass: MIT Press.

Price, R.G. 2011. Understanding Capitalism. Lulu.com.

Public Health Act 1925 S.17-19. http://www.legislation.gov.uk/ukpga/Geo5/15$16 / 71$.

Scollon, R. and S. Scollon (2003) Discourses in Place: Language in the Material World. Abingdon: Routledge.

Smoke-free (Premises and Enforcement) Regulations, The 2006. http://www.legislation. gov.uk/uksi/2006/3368/contents/made

Spolsky, B. (2009) Prolegomena to a sociolinguistic theory of public signage. In E. Shohamy and D. Gorter (eds) Linguistic Landscapes: Expanding the Scenery, Abingdon, Oxon: Routledge, 25-39.

Tschichold, J. (1928/1998). The New Typography. Reprinted in English translation by R. McLean, Berkeley, CA: University of California Press (1998).

Tuan, Y-F. (1991) Language and the making of place: a narrative-descriptive approach. Annals of the Association of American Geographers, 81: 4.

Venturi, R., D.S. Brown, and S. Izenour (1997). Learning from Las Vegas. Revised Edition. Cambridge, Mass: MIT Press. First published 1972.

Zukin, S., P. Kazintz and X. Chen (2016) Global Cities, Local Streets. London: Routledge. 
